Portland State University

PDXScholar

2016

\title{
A Comparative Study of the Performance Capabilities of Magnetic Gears
}

D. S. Painter

Portland State University

Follow this and additional works at: https://pdxscholar.library.pdx.edu/honorstheses

Let us know how access to this document benefits you.

\section{Recommended Citation}

Painter, D. S., "A Comparative Study of the Performance Capabilities of Magnetic Gears" (2016). University Honors Theses. Paper 307.

https://doi.org/10.15760/honors.316

This Thesis is brought to you for free and open access. It has been accepted for inclusion in University Honors Theses by an authorized administrator of PDXScholar. Please contact us if we can make this document more accessible: pdxscholar@pdx.edu. 


\section{Portland State University}

PDXScholar

\section{A Comparative Study of the Performance Capabilities of Magnetic Gears}

Dana Painter

Let us know how access to this document benefits you.

Follow this and additional works at: http://pdxscholar.library.pdx.edu/honorstheses

This Thesis is brought to you for free and open access. It has been accepted for inclusion in University Honors Theses by an authorized administrator of PDXScholar. For more information, please contact pdxscholar@pdx.edu. 


\title{
A Comparative Study of the Performance Capabilities of Magnetic Gears
}

\author{
D. S. Painter
}

\begin{abstract}
This article is a literature review and comparison of the performance capabilities of magnetic gears. The purpose of this paper was to determine the validity of further attempts at implementing magnetic gear technology into large scale applications such as wind turbines. It was determined that mechanical gears still carry an advantage over magnetic gears in terms of performance; magnetic gears have only reached a peak torque performance of $731 \mathrm{Nm}$. The highest torque density for a magnetic gear is $239 \mathrm{Nm} / \mathrm{L}$. Improvements in magnetic gears, such as, the types of magnets used, and improved topologies of the gears have been significant factors in improving the performance of magnetic gears. Such improvements signify that there is potential in magnetic gear technology, and that further research in designing high performing magnetic gears could potentially lead to a viable replacement for mechanical gears.
\end{abstract}

Index Terms-- gear-box, magnetic gears, mechanical gears, direct drive machines, torque density, magnetic shear stress.

\section{INTRODUCTION}

$\mathrm{T}$ HIS paper compares the performance between magnetic gears, electric machines and mechanical gears, by comparing torque, torque density, and shear stress.

Mechanical gears are typically used in large scale applications such as wind turbines; and though they are an efficient option, they often have reliability issues [1]. One solution, has been to design or repurpose a magnetic gear, which is much more reliable due to its contactless operation and inherit overload capability. The first magnetic gear was introduced in 1916 by Armstrong, C. G as a U.S patent "Power Transmitting Device" [2], and was developed further in 1941, by H.T Faus [3]. These early designs had poor performance due to their poor use of the magnetic material and the low energy magnetic material available. Since the introduction of rare earth magnets, there have been several publications that describe significantly higher performing magnetic gear topologies [4-19]; the progression from lower to higher performing gears is described in Figures 1-3. The history of magnetic gear development has been well recorded, and allows one to look at their limitations, and their potential. The potential that magnetic gears have could make renewable energies such as wind power more cost effective in the long run due to their reliability, and the only obstacle in the field is to build a high performing magnetic gear, comparable to a mechanical gear. Some papers have focused on the improvements that magnetic gears offer in large scale

This work was supported in part by a N.C. Coastal Studies Institute Ocean Energy Grant.

D. Painter Portland State University, Portland, OR, 97201. (e-mail: dpainter@pdx.edu) applications such as wind turbines, [4], [5], [11], as well as oceanic powered generators [20].

To build a prototype of a magnetic gear, large enough to run a wind turbine, to test is extremely expensive. However, a few papers have been published recently that describe magnetic gears with relatively large torque densities.

As mechanical gears have high torque performances, they have been the most obvious option for use in wind turbines, however surges often cause mechanical issues which are very expensive to fix [1]. This issue is ever growing as wind turbines move off-shore, where wind speeds are higher, and service becomes far costlier. By using magnetic gears, the reliability of gears used in wind turbines can be increased, and therefore the cost of using wind as a source of renewable energy decreases.

\section{A. Math and Equations}

The outer rotor volumetric torque density, $T_{D O}$, is defined as,

$T_{D O}=\frac{T_{M}}{\pi r_{o}{ }^{2} d}$

where $T_{M}$ is the measured peak torque, $r_{o}$ is the outer radius of the outer rotor, and $d$ is the active region stack length of the gear. The inner rotor volumetric torque density is defined as,

$T_{D i}=\frac{T_{M}}{\pi r_{i}^{2} d}$

where $r_{i}$ is the outer radius of the inner rotor. The magnetic shear stress, $\sigma_{D}$, is defined as,

$\sigma_{D}=\frac{F}{2 \pi r_{\text {air }} d}$

where $r_{\text {air }}$, is the radius of the outer air gap. By comparing (1) and (2) and noting that torque and force are related by, $\mathrm{T}=\mathrm{Fr}$, the magnetic shear stress can be related to the torque density as follows,

$2 \sigma_{D}=T_{D i}$

where $T_{D i}$ is the inner rotor volumetric torque density in

$\mathrm{Nm} / \mathrm{m}^{3}$, and $\sigma_{D}$ is the magnetic shear stress in $\mathrm{kN} / \mathrm{m}^{2}$.

The mass torque density was also determined in $\mathrm{Nm} / \mathrm{kg}$ with the following conversion;

$T_{D}=\frac{T_{M}}{\pi r_{o}{ }^{2} d \rho}$

where $\rho$ is the density of steel, or $7.85 \mathrm{~kg} / \mathrm{L}$. this equation was applied in determining the upper bound of the mass torque density in $\mathrm{Nm} / \mathrm{kg}$ when the mass or weight was not already given. 


\section{B. Methods}

This study will be conducted in the form of a literature review. By using primary data from studies done on magnetic gears, mechanical gears, and direct drive generators. The experimental, and calculated results were then placed in tables, which describe the performance of the different magnetic and mechanical gear models. The torque density was calculated using (1), and the shear stress was calculated using (3). The time line, and the amount of models that will be described will provide a comprehensive perspective on the magnetic and mechanical gear performances. In order to compare the different gears without causing bias, the mechanical gears selected followed similar parameters of the magnetic gears that have been developed.

Magnetic and mechanical gears were compared in this study by calculating torque densities, using the given parameters, and torque ratings, of each gear. These values as well as the magnetic shear stress of the magnetic gears were then described in Figures 2-5. The performances of the magnetic and mechanical gears will also be compared with the performance of electric machines. The following figure describes a common topology of the magnetic gears that were reviewed in this study.

Rotor 1: $\mathrm{P}_{1}$ magnet pole-pairs

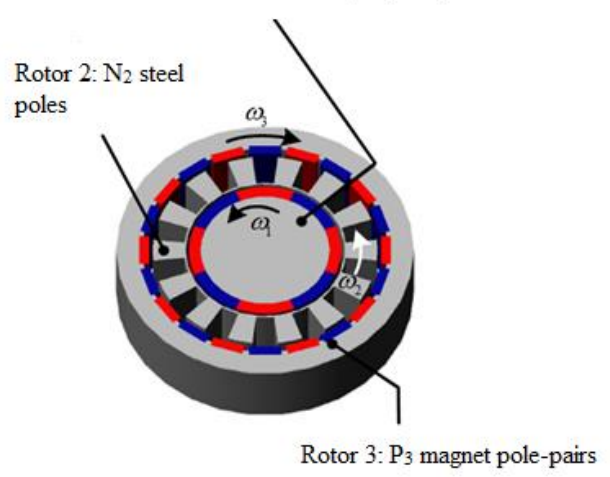

Fig. 1. General layout of a coaxial magnetic gear [15].

\section{Comparative Tables}

Table I shows torque density and shear stress for the magnetic gears. Table II shows the torque and torque density for mechanical gears [21], [22] and Table III shows torque, torque density and shear stress for direct drive machines. There are several trends to be acknowledged; for one, the shear stress and torque densities for the magnetic gear is higher than for the direct drive motors, also there are larger improvements in magnetic gears, in the last twenty years, and that magnetic gears are catching up to mechanical gears in performance ratings in terms of torque density. There is still room to improve, further testing, and prototype evaluations could potentially offer further improvements especially at larger radii.

\section{Magnetic Gears}

TABLE I

DATA COLLECTED AND CALCULATED FROM THE DIMENSIONS AND EXPERIMENTAL RESULTS FROM MAGNETIC GEARS

\begin{tabular}{|c|c|c|c|c|c|}
\hline Author & $\begin{array}{c}\text { Outer } \\
\text { Radius } \\
\text { (m) }\end{array}$ & $\begin{array}{c}\text { Measured } \\
\text { Torque } \\
\text { (Nm) }\end{array}$ & $\begin{array}{l}\text { Torque } \\
\text { Density } \\
(\mathrm{Nm} / \mathrm{L})\end{array}$ & $\begin{array}{l}\text { Torque } \\
\text { Density }\end{array}$ & $\begin{array}{l}\text { Shear } \\
\text { stress }\end{array}$ \\
\hline [4] & 0.11 & 731 & 239 & 30 & 168 \\
\hline [5] & 0.10 & 146 & 123 & 16 & 80 \\
\hline [6] & 0.04 & 64 & 111 & 14 & 13 \\
\hline [7] & 0.11 & 156 & 108 & 14 & - \\
\hline [8] & 0.10 & 140 & 99 & 13 & - \\
\hline [9] & 0.07 & 169 & 98 & 12 & 84 \\
\hline$[10]$ & 0.12 & 220 & 92 & 10 & 32 \\
\hline [11] & 0.09 & 96 & 90 & 11 & 51 \\
\hline [12] & 0.10 & 100 & 85 & 11 & 54 \\
\hline [13] & 0.06 & 33 & 81 & 10 & 48 \\
\hline [14] & 0.07 & 62 & 80 & 10 & 50 \\
\hline [15] & 0.07 & 60 & 78 & 10 & 60 \\
\hline [14] & 0.07 & 59 & 76 & 10 & 58 \\
\hline [16] & 0.12 & 600 & 68 & 9 & 39 \\
\hline [20] & 0.06 & 93 & 64 & 8 & 60 \\
\hline [18] & 0.07 & 13 & 63 & 8 & 44 \\
\hline [19] & 0.06 & 16 & 54 & 7 & 32 \\
\hline [23] & 0.11 & 73 & 53 & 7 & 41 \\
\hline [24] & 0.07 & 40 & 52 & 7 & 40 \\
\hline [25] & 0.06 & 12 & 42 & 5.33 & 27 \\
\hline [26] & 0.25 & 1066 & 41 & 2 & 21 \\
\hline [27] & 0.08 & 75 & 34 & 4 & 30 \\
\hline [28] & 0.05 & 5 & 29 & 4 & 24 \\
\hline [29] & 0.07 & 33 & 29 & 4 & 19 \\
\hline [30] & 0.26 & 716 & 27 & 3 & 14 \\
\hline [31] & 0.18 & 475 & 23 & 3 & 15 \\
\hline [32] & 0.09 & 15 & 15 & 2 & 12 \\
\hline [33] & 0.18 & 100 & 13 & 2 & - \\
\hline
\end{tabular}

\section{E. Mechanical Gears}

TABLE II

DATA COLLECTED FROM MECHANICAL GEARS

\begin{tabular}{|c|c|c|c|c|}
\hline Model & $\begin{array}{c}\text { Outer } \\
\text { Radius } \\
{[\mathbf{m}]}\end{array}$ & $\begin{array}{c}\text { Torque } \\
{[\mathbf{N m}]}\end{array}$ & $\begin{array}{c}\text { Torque } \\
\text { Density } \\
{[\mathbf{N m} / \mathbf{L}]}\end{array}$ & $\begin{array}{c}\text { Torque } \\
\text { Density } \\
{[\mathbf{N m} / \mathbf{k g}]}\end{array}$ \\
\hline Atlas & 0.28 & 3163 & 47 & 18 \\
\hline Venus & 0.16 & 1808 & 82 & 11 \\
\hline Polaris & 0.20 & 5875 & 122 & 15 \\
\hline Neptune & 0.28 & 9039 & 124 & 17 \\
\hline Earth & 0.21 & 4971 & 125 & 19 \\
\hline Orion Plus & 0.28 & 16269 & 141 & 16 \\
\hline Luna & 0.16 & 4519 & 204 & 26 \\
\hline Neptune plus & 0.28 & 16043 & 219 & 26 \\
\hline GBPN-1601-005 & 0.07 & 450 & 281 & 25 \\
\hline GBPN-0401-005 & 0.02 & 14 & 286 & 38 \\
\hline GBPN-0601-005 & 0.03 & 40 & 301 & 44 \\
\hline GBPH-0601-NP-005 & 0.03 & 48 & 340 & 41 \\
\hline GBPN-0801-005 & 0.04 & 110 & 362 & 53 \\
\hline GBPH-0901-NS-005 & 0.05 & 155 & 366 & 44 \\
\hline GBPH-0901-NP-005 & 0.05 & 180 & 475 & 56 \\
\hline GBPH0601-NS-005 & 0.03 & 55 & 486 & 45 \\
\hline GBPN-1201-005 & 0.06 & 390 & 507 & 65 \\
\hline GBPH-1501-NP-005 & 0.07 & 536 & 513 & 41 \\
\hline GBPH-1801-NP-005 & 0.09 & 1248 & 545 & 35 \\
\hline GBPH-0601-CS-005 & 0.03 & 47 & 573 & 43 \\
\hline GBPH-1201-NP-005 & 0.06 & 292 & 584 & 64 \\
\hline GBPH-0901-CS-005 & 0.05 & 155 & 607 & 44 \\
\hline
\end{tabular}




\section{F. Direct Drive Machines}

TABLE III

DATA COLLECTED FROM THE DIMENSIONS AND EXPERIMENTAL RESULTS FOR DIRECT DRIVE MACHINES

\begin{tabular}{|c|c|c|c|c|c|}
\hline Author/Model & $\begin{array}{c}\text { Outer } \\
\text { Radius } \\
\text { [m] }\end{array}$ & $\begin{array}{c}\text { Peak } \\
\text { Torque } \\
\text { [Nm] }\end{array}$ & $\begin{array}{l}\text { Torque } \\
\text { Density } \\
{[\mathrm{Nm} / \mathrm{L}]}\end{array}$ & $\begin{array}{l}\text { Torque } \\
\text { Density } \\
{[\mathrm{Nm} / \mathrm{kg}]}\end{array}$ & $\begin{array}{c}\text { Magnetic } \\
\text { Shear } \\
\text { Stress } \\
{\left[\mathbf{k N} / \mathbf{m}^{2}\right]} \\
\end{array}$ \\
\hline [34] & 0.36 & 153 & 2.6 & 0.3 & 1.3 \\
\hline $\mathrm{AC}-75[35]$ & 0.15 & 122 & 6.7 & 3.6 & 3.3 \\
\hline $\mathrm{AC}-150[35]$ & 0.15 & 225 & 9.5 & 4.5 & 4.8 \\
\hline$[36] \mathrm{F}$ & 0.21 & 720 & 10.0 & 1.3 & 5.0 \\
\hline$[36] \mathrm{B}$ & 0.04 & 8 & 13.6 & 1.7 & 6.8 \\
\hline [36] A & 0.04 & 9 & 25.7 & 3.3 & 12.8 \\
\hline$[36] \mathrm{E}$ & 0.11 & 220 & 26.3 & 3.4 & 13.2 \\
\hline [36]D & 0.09 & 91 & 29.8 & 3.8 & 14.9 \\
\hline [36] C & 0.05 & 19 & 33.7 & 4.3 & 16.8 \\
\hline$[37]$ & 0.07 & 60 & 52.6 & 6.7 & 26.3 \\
\hline
\end{tabular}

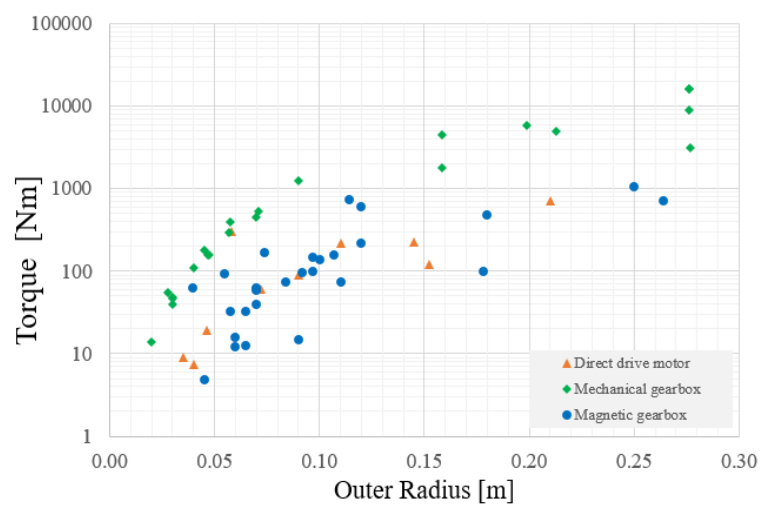

Fig. 2. Torque as a function of the outer radius of the outer rotor for mechanical gears, magnetic gears, and direct drive machines for comparison.

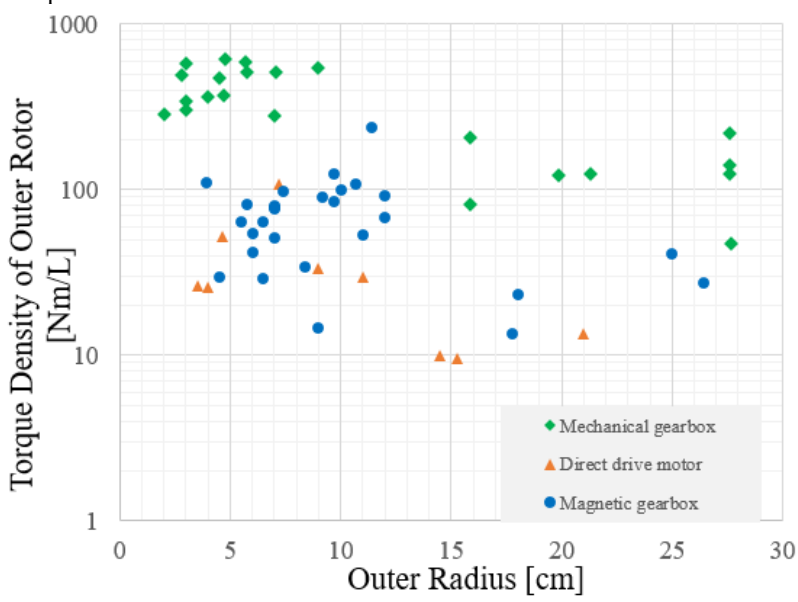

Fig. 3. Torque density as a function of the outer radius of the outer rotor for mechanical gears, magnetic gears, and direct drive machines for comparison.

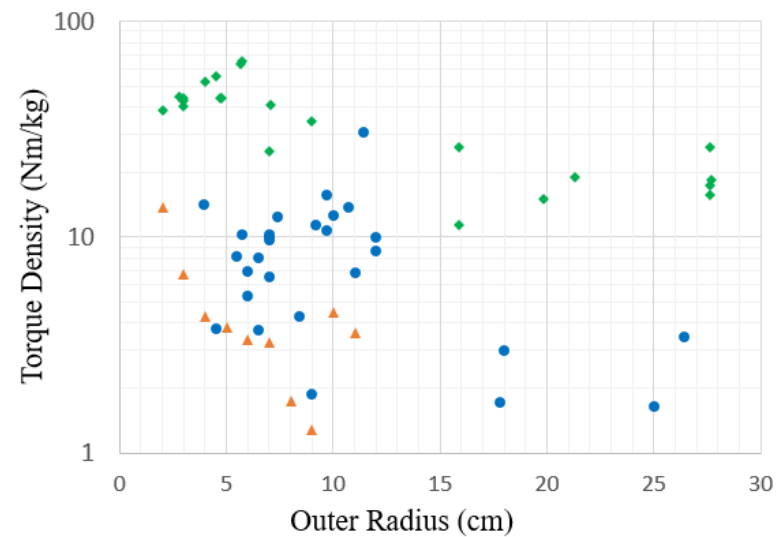

Fig. 4. Torque density in $(\mathrm{Nm} / \mathrm{kg})$ as a function of the outer radius of the outer rotor for mechanical gears, magnetic gears, and direct drive machines for comparison.

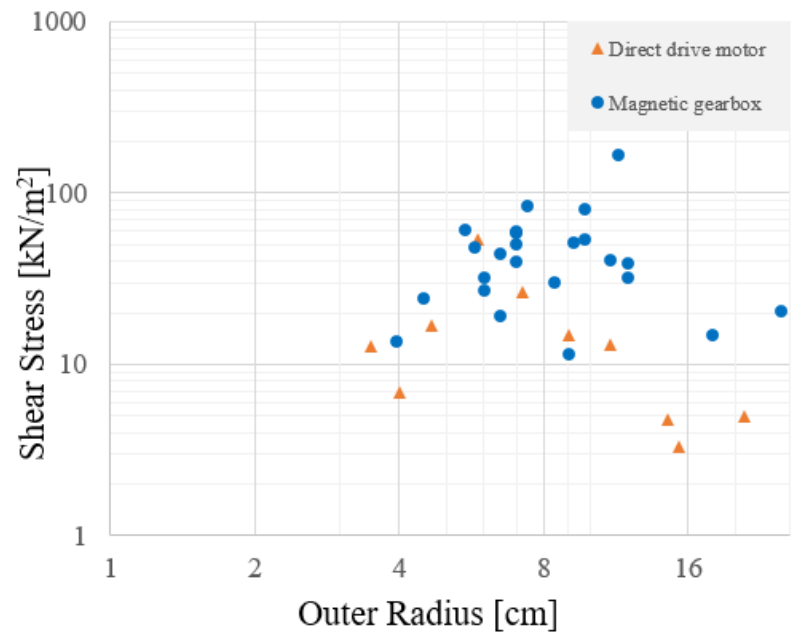

Fig. 5. Magnetic Shear Stress in $\left(\mathrm{kN} / \mathrm{m}^{2}\right)$, using properties of (2), as a function of the outer radius of the outer rotor for, magnetic gears, and direct drive machines for comparison.

\section{CONCLUSION}

Based on the models of gears explored in this research, there is evidence suggesting that magnetic gears have the potential to achieve relatively high torque densities when compared with mechanical gears; this is particularly so for large diameter magnetic gears. This paper has tried to illustrate what many have suggested in the past, that when looking at mechanical and magnetic gear performances, magnetic gears have to further catch up to mechanical gears when it comes to performance, however a lot of progress has been made fairly quickly in the last few decades. The highest torque density this study found was $239 \mathrm{Nm} / \mathrm{L}$ [4], which is significant. This study suggests that magnetic gears are not only more reliable, and therefore more cost effective, they also could potentially be a viable substitution for mechanical gears, at higher torque values. 


\section{REFERENCES}

1. Musial, W., S. Butterfield, and B. McNiff. Improving wind turbine gearbox reliability. in European Wind Energy Conference, Milan, Italy. 2007.

2. Armstrong, C.G., Power-transmitting device. 1901, Google Patents.

3. Faus, H.T., Magnet gearing. 1941, Google Patents.

4. Uppalapati, K., et al. A magnetic gearbox with an active region torque density of $239 \mathrm{Nm} / \mathrm{L}$. in Energy Conversion Congress and Exposition (ECCE), 2014 IEEE. 2014. IEEE.

5. Du, S., Y. Zhang, and J. Jiang. Research on a novel combined permanent magnet electrical machine. in Electrical Machines and Systems, 2008. ICEMS 2008. International Conference on. 2008. IEEE.

6. Bomela, W., J.Z. Bird, and V.M. Acharya, The performance of a transverse flux magnetic gear. IEEE transactions on magnetics, 2014. 50(1)

7. Jian, L., et al., Comparison of coaxial magnetic gears with different topologies. Magnetics, IEEE Transactions on, 2009. 45(10): p. 4526-4529.

8. Mezani, S., K. Atallah, and D. Howe, A high-performance axialfield magnetic gear. Journal of applied physics, 2006. 99(8): p. 08R303.

9. $\mathrm{Li}, \mathrm{X}$., et al. An improved coaxial magnetic gear using flux focusing. in Electrical Machines and Systems (ICEMS), 2011 International Conference on. 2011. IEEE.

10. Rasmussen, P.O., et al., Experimental evaluation of a motorintegrated permanent-magnet gear. Industry Applications, IEEE Transactions on, 2013. 49(2): p. 850-859.

11. Jian, L., K. Chau, and J. Jiang, A magnetic-geared outer-rotor permanent-magnet brushless machine for wind power generation. Industry Applications, IEEE Transactions on, 2009. 45(3): p. 954-962

12. Chau, K., et al., Transient analysis of coaxial magnetic gear using finite element comodeling. Journal of Applied Physics, 2008. 103(7): p. 07F101.

13. Bronn, L., R. Wang, and M. Kamper. Development of a shutter type magnetic gear. in Proceedings of the 19th Southern African Universities Power Engineering Conference (SAUPEC). 2010

14. Gerber, S. and R.-J. Wang. Torque capability comparison of two magnetically geared PM machine topologies. in Industrial Technology (ICIT), 2013 IEEE International Conference on. 2013. IEEE.

15. Atallah, K., S. Calverley, and D. Howe. Design, analysis and realisation of a high-performance magnetic gear. in Electric Power Applications, IEE Proceedings-. 2004. IET

16. Frandsen, T.V., P.O. Rasmussen, and K.K. Jensen. Improved motor intergrated permanent magnet gear for traction applications. in Energy Conversion Congress and Exposition (ECCE), 2012 IEEE. 2012. IEEE.

17. Uppalapati, K. and J. Bird. A flux focusing ferrite magnetic gear. in IET Conference Proceedings. 2012. The Institution of Engineering \& Technology.

18. Shah, L., A. Cruden, and B.W. Williams, A variable speed magnetic gear box using contra-rotating input shafts. Magnetics, IEEE Transactions on, 2011. 47(2): p. 431-438.

19. Rasmussen, P.O., et al., Development of a high-performance magnetic gear. Industry Applications, IEEE Transactions on, 2005. 41(3): p. 764-770.

20. Uppalapati, K.K., et al. Performance of a magnetic gear using ferrite magnets for low speed ocean power generation. in Energy Conversion Congress and Exposition (ECCE), 2012 IEEE. 2012. IEEE.

21. Nabtesco. Available from: http://www.nabtescomotioncontrol.com/products/rd2-seriesgearbox/.

22. REXNORD. Planetgear 7000 Speed Reducer: Proven, Reliable, Rugged. 2007; Available from: http://www.norfolkbearings.com/products/rex/REXPLANETGEAR.pdf.
23. Liu, X., et al., Design and analysis of interior-magnet outerrotor concentric magnetic gears. Journal of Applied Physics, 2009. 105(7): p. 07F101.

24. Johnson, M., et al. Analysis and development of an axial flux magnetic gear. in Energy Conversion Congress and Exposition (ECCE), 2014 IEEE. 2014. IEEE.

25. Frank, N.W. and H.A. Toliyat, Analysis of the concentric planetary magnetic gear with strengthened stator and interior permanent magnet inner rotor. Industry Applications, IEEE Transactions on, 2011. 47(4): p. 1652-1660.

26. Acharya, V.M., J.Z. Bird, and M. Calvin, A flux focusing axial magnetic gear. IEEE transactions on magnetics, 2013. 49(7): $\mathrm{p}$ 4092-4095

27. Lubin, T., S. Mezani, and A. Rezzoug, Analytical computation of the magnetic field distribution in a magnetic gear. Magnetics, IEEE Transactions on, 2010. 46(7): p. 2611-2621.

28. Niguchi, N. and K. Hirata, Cogging torque analysis of magnetic gear. Industrial Electronics, IEEE Transactions on, 2012. 59(5): p. 2189-2197.

29. Jørgensen, F.T., T.O. Andersen, and P.O. Rasmussen. The cycloid permanent magnetic gear. in Industry Applications Conference, 2006. 41st IAS Annual Meeting. Conference Record of the 2006 IEEE. 2006. IEEE.

30. Rasmussen, P.O., et al. Motor integrated permanent magnet gear with a wide torque-speed range. in Energy Conversion Congress and Exposition, 2009. ECCE 2009. IEEE. 2009. IEEE.

31. Holehouse, R.C., K. Atallah, and J. Wang, Design and realization of a linear magnetic gear. Magnetics, IEEE Transactions on, 2011. 47(10): p. 4171-4174.

32. Fujita, T., et al., Surface magnet gears with a new magnet arrangement and optimal shape of stationary pole pieces. 2013.

33. Atallah, K., et al., A novel "Pseudo" direct-drive brushles permanent magnet machine. Magnetics, IEEE Transactions on, 2008. 44(11): p. 4349-4352.

34. Spooner, E. and A. Williamson. Parasitic losses in modular permanent-magnet generators. in Electric Power Applications, IEE Proceedings-. 1998. IET.

35. Anaheim Automation. Available from http://anaheimautomation.com/marketing/servo/servodrives.php.

36. Jurkovic, S., et al., Induction machine design and analysis for General Motors e-Assist electrification technology. Industry Applications, IEEE Transactions on, 2015. 51(1): p. 631-639.

37. Burress, T.A., et al., Evaluation of the 2010 Toyota Prius hybrid synergy drive system. 2011, Oak Ridge National Laboratory (ORNL); Power Electronics and Electric Machinery Research Facility. 